\title{
Dental management of pediatric patients affected by pulmonary atresia with ventricular septal defect: A scoping review
}

\author{
Arturo Garrocho-Rangel ${ }^{1}$, Ana-Cristina Echavarría-García ${ }^{2}$, Miguel-Ángel Rosales-Bérber ${ }^{3}$, Joselín Flores- \\ Velázquez $^{4}$, Amaury Pozos-Guillén ${ }^{5}$
}

\begin{abstract}
${ }^{1}$ DDS, MSc, PhD, Especialidad en Estomatología Pediátrica, Facultad de Estomatología, Universidad Autónoma de San Luis Potosí, San Luis Potosí, S.L.P., México

${ }^{2}$ DDS, Especialidad en Estomatología Pediátrica, Facultad de Estomatología, Universidad Autónoma de San Luis Potosí, San Luis Potosí, S.L.P., México

${ }^{3}$ DDS, MSc, Especialidad en Estomatología Pediátrica, Facultad de Estomatología, Universidad Autónoma de San Luis Potosí, San Luis Potosí, S.L.P., México

${ }^{4}$ DDS, Especialidad en Estomatología Pediátrica, Facultad de Estomatología, Universidad Autónoma de San Luis Potosí, San Luis Potosí, S.L.P., México

${ }^{5}$ DDS, MSc, PhD, Laboratorio de Ciencias Básicas, Facultad de Estomatología, Universidad Autónoma de San Luis Potosí, San Luis Potosí, S.L.P., México
\end{abstract}

Correspondence:

Facultad de Estomatología

Universidad Autónoma de San Luis Potosí

Av. Dr. Manuel Nava \#2, Zona Universitaria

C.P. 78290; San Luis Potosí, S.L.P. México

apozos@uaslp.mx

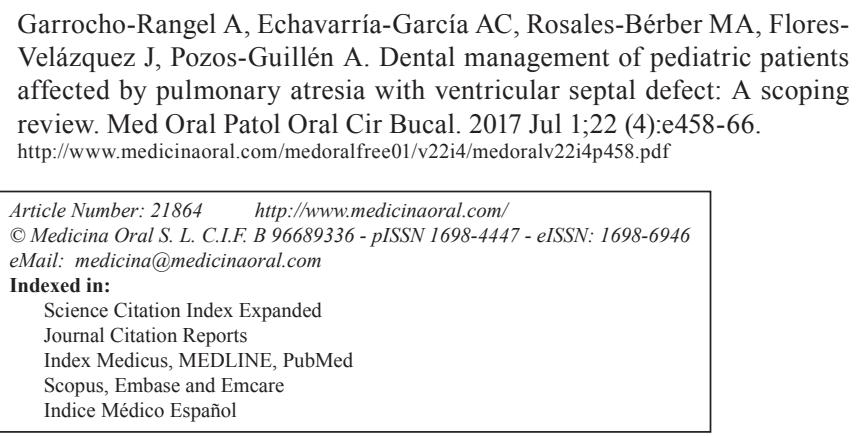

\begin{abstract}
Background: Congenital Heart Diseases (CHD) involves a wide range of pathological conditions, such as Pulmonary Atresia with Ventricle Septal Defect (PA/VSD). This disorder leads to the systemic circulation of oxygenpoor blood (cyanosis), with associated features and consequences in the oral cavity.

Material and Methods: Using scoping review methodology for screening and article selection, the primary objectives of this paper were as follows: first, to pose a research question; second, to identify relevant studies in order to answer the research question; third, to select and retrieve the studies; fourth, to chart the critical data, and finally, to collate, summarize, and report the results from the most important articles on the dental management of children affected with PA/VSD. Relevant articles (Randomized Controlled Trials [RCT], reviews, observational studies, and clinical case reports) published over a 10-year period were identified and retrieved from four Internet databases: PubMed; Embase/Ovid; Cochrane Library, and Google Scholar.

Results: By title and abstract screening and after removing duplicates, 24 articles were finally included in the present scoping review. According to the extracted data, the following are the most important clinical issues to be considered when treating children with PA/VSD in the dental setting: prevalence of dental caries; prevention
\end{abstract}


of dental disease (oral hygiene and diet); bacteremia and infective endocarditis risk, and child behavior control and treatment under general anesthesia.

Conclusions: Pediatric Dentists should bear in mind that early diagnosis and treatment, together a long-term followup of children with PA/VSD, continue to be the best approaches for achieving enhanced patient psychological wellbeing and, in consequence, their good quality of life.

Key words: Pulmonary atresia, congenital heart diseases, ventricle septal defect, scoping review, dental management.

\section{Introduction}

Tetralogy of Fallot (TF) is the most common form of Congenital Heart Disease (CHD), which is characterized by the association of four cardiac abnormalities $(1,2)$ : (i) maligned ventricular septal defect; (ii) subpulmonary stenosis; (iii) overriding aorta, and (iv) right ventricular hypertrophy. TF accounts for around $10 \%$ of all CHD, with a prevalence of $>2$ per 10,000 births, with males affected more than females (3-5).

Pulmonary Stenosis with Ventricular Septal Defect (PS/ VSD) in pediatric patients represents the most severe form of this disease spectrum (1). In these cases, no direct communication exists between the heart right ventricle and the lungs; consequently, there is a partial or complete obstruction of the blood flow from right ventricle to the pulmonary circulation. Thus, to maintain blood flow to the lung, higher ventricle pressure is generated, which is manifested as compensatory right ventricle hypertrophy. These abnormal events lead to the systemic circulation of oxygen-poor (desaturated) blood (6). In severe cases, a right-to-left shunting through the foramen ovale is formed, which is manifested by cyanosis, acropachy, polycythemia, systemic hypoxia, anemia, bluish appearance, and clubbing of the fingers $(4,6)$. The etiology of TF continues to remain unclear, but it has been related with defects occurring from week 3 to week 8 of intrauterine life $(7,8)$. Likewise, several associated conditions have been mentioned as follows: low birth weight; short gestational duration; rubella; maternal infections; smoking or alcoholism; drugs such as Thalidomide, Warfarin, and Phenytoin, and, possibly, twinning $(4,8)$. Gene mutations have been suggested in $4 \%$ of TF cases (9). Approximately $21 \%$ of TF have been associated with diverse syndromes, for instance, Down syndrome, Noonan syndrome, Branchial Arch syndrome, and chromosome 22q11 microdeletion $(4,10)$. During the last 20 years, medical and surgical techniques have substantially improved, and $>80 \%$ of affected children reach adulthood (10); pediatric survival is rare in the absence of surgical intervention and depends mainly on the adequacy of the patient's pulmonary collateral circulation.

Similar to other congenital heart defects, PSD/VSD impacts upon dental health with respect to three different issues: dentition development; risk of infective endocarditis from bacteremia induced by invasive den- tal procedures, and special implications with treatment delivered when required $(1,3,11)$. Regarding the first point, ameloblasts are extremely sensitive to metabolic alterations, for example, in cases of CHD, during tooth formation, which can lead to the formation of a thinner and/or softer enamel tissue; in consequence, these teeth are more susceptible to faster destruction due to caries and are more difficult to restore. Other oral abnormal findings include delayed tooth eruption, stomatitis, glossitis, cyanotic mucus membrane, tongue, and gingiva $(7,12)$. Therefore, it is necessary to conduct an early oral examination, followed by the promotion of individual hygiene measures and the implementation of therapeutic procedures in children affected by PSD/ VSD $(11,13)$. Despite recent medical progress, CHD are still a cause of high mortality in pre-school children, accounting for one half of deaths in this age group (8). In this context, the present article aims to present the main results of a scoping review on the dental management of patients with PSD/VSD performed over a period of the last 10 years.

\section{Material and Methods}

A scoping review was conducted between November 2016 and January 2017. We implemented the Arksey and O'Malley methodological framework and recommendations for this type of review (14).

- Research question

The present review intended to answer the following research question: What are the current best dental management approaches for children and adolescents suffering from pulmonary atresia with ventricular septal defect?

- Identifying relevant studies

The present scoping review's primary objectives were the following: to pose a research question; to identify and retrieve relevant studies; to select studies relevant to the research question in order to chart critical data from the selected studies, and finally, to collate, summarize, and report the results from the most important articles on PA/VSD in children and adolescents that were published between January 1990 and December 2016, in order to answer the previously posed research question. These articles were accessible on four Internet electronic databases: MEDLINE (via PubMed); Embase/Ovid; the Cochrane Library, and Google Scholar. The search strategy was appropriately adapted for each 
database. The main search terms, MeSH, or free-text terms, keywords, and Boolean operators, alone or in combination, chosen for these aims included "congenital heart disease", "tetralogy of Fallot", "pulmonary atresia", "ventricular septal defect", "cyanosis", "children", "adolescents", "pediatric dentistry", "dentistry for children", and "pedodontics". The filter 'Age' was set at 'Child: birth-18 years'. The search algorithm is described in Table 1.

- Study screening and selection

The titles and abstracts that were considered reliable, derived from electronic searches, were carefully reviewed by three authors (ACE-G, JF-V, and MAR-B), by independent screening, to select the most relevant studies for inclusion in the review. Different types of peer-reviewed publications, in the English or Spanish languages, were screened as follows: prospective clinical trials (parallel groups or cross-over designs); observational or descriptive studies (cohort, case-control, and cross-sectional studies); pilot studies; narrative reviews of the literature; in vitro studies; clinical case series, and case reports. The following articles were excluded: studies involving solely adults; patients with other systemic/ syndromic conditions, and purely laboratory investigations. A complementary hand-search in the reference lists of selected articles was also performed; then, the eligible articles, in their full-text form, were obtained. The reported outcome extraction process -employing a predesigned and standardized form- was carried out by other two experienced authors (JAG-R and AJP-G), also in an independent manner, and any disagreement or discrepancy was resolved by discussion and consensus. Specifically, relevant clinical information on the pediatric dental management of PA/VSD was searched for extraction, such as diagnostic methods, oral hygiene/prevention approaches, dental consequences of the disease, special medical considerations (including potential side effects), restorative/pulpal/surgical interventions in primary and young permanent teeth, orthodontics/dentofacial-orthopedics treatment modalities, and oral health maintenance (control and follow-up). A judgment concerning whether each outcome was primarily clinician-centered was also carried out. The flow chart for the entire article-search process is depicted in Figure 1. Finally, a descriptive statistical analysis for the studies included was performed. This analysis involved relevant methodological characteristics from each chosen study, such as design, aim, sample size, population type, follow-up period, and others; also, main clinical findings, medical considerations and dental management were included. These features were summarized through specific Tables 2-4.

\section{Results}

- Charting the Data

The initial electronic database search yielded a total of
96 potential articles. By title and abstract screening and after removing duplicates, 41 articles were included. These were retrieved in full-text and analyzed; an additional hand-search was also performed. Finally, 24 articles were included in the present scoping review (23 in English and 1 in Spanish) for the pertinent informationextraction process. Figure 1 describes the flow diagram of eligible studies.

- Collating, Summarizing, and Reporting the Results After exploring the final selection of articles, a large amount of relevant clinical information was able to be condensed. Main findings from this process are outlined as follows (see Table 2) (15-29).

\section{Discussion}

Knowledge synthesis is currently essential to advance clinical health-science practice and research through consolidation of evidence and to aid practitioners to make a more efficient process of evidence-base decision $(30,31)$. In this regard, scoping reviews are increasingly undertaken as a popular approach to review sufficient health-research evidence $(14,32)$. This type of literature review involves the synthesis and analysis of a wide range of literature and research, including clinical oral health care (31), with rapid 'mapping' of the key concept from the relevant literature and providing general conceptual clarity about a specific topic or field of evidence $(14,33)$. Scoping reviews are different from and more flexible in terms of design than systematic reviews. First, systematic reviews focus on a well-defined question and appropriate specific study designs can be identified in advance, while scoping reviews tend to address broader topics in which different study designs may be applicable. In second place, systematic reviews aim to provide answers to the posed question from quality assessed studies; a scoping review does not intend to address very specific questions, nor, consequently, it does not incorporate a quality assessment of the selected primary studies (31). The significance of scoping reviews lies in their main purposes as follows: (i) to examine the extent, range, and nature of research activity; (ii) to determine the value of performing a systematic review; (iii) to summarize and disseminate relevant research findings, and (iv) to identify research gaps in the existing health literature $(14,30,32,33)$.

According to the results of the present review, the following four main clinical considerations may be established and discussed in order to increase the probability of achieving proper management of CHD-affected children in clinical pediatric dentistry, specifically those with pulmonary atresia with ventricular septal defect: (i) prevalence of dental caries; (ii) prevention of dental disease (oral hygiene and diet); (iii) bacteremia and infective endocarditis risk, and (iv) child behavior control and treatment under general anesthesia. 
Table 1. Search strategy

(("Congenit Heart Dis"[Journal] OR ("congenital"[All Fields] AND "heart"[All Fields] AND "disease"[All Fields]) OR "congenital heart disease"[All Fields]) OR ("tetralogy of fallot"[MeSH Terms] OR ("tetralogy"[All Fields] AND "fallot"[All Fields]) OR "tetralogy of fallot"[All Fields]) OR ("pulmonary atresia"[MeSH Terms] OR ("pulmonary"[All Fields] AND "atresia"[All Fields]) OR "pulmonary atresia"[All Fields]) OR ("heart septal defects, ventricular"[MeSH Terms] OR ("heart"[All Fields] AND "septal"[All Fields] AND "defects"[All Fields] AND "ventricular"[All Fields]) OR "ventricular heart septal defects"[All Fields] OR ("ventricular"[All Fields] AND "septal"[All Fields] AND "defect"[All Fields]) OR "ventricular septal defect"[All Fields]) OR ("cyanosis"[MeSH Terms] OR "cyanosis"[All Fields])) AND ("child"[MeSH Terms] OR "child"[All Fields] OR "children"[All Fields]) AND (("paediatric dentistry"[All Fields] OR "pediatric dentistry"[MeSH Terms] OR ("pediatric"[All Fields] AND "dentistry"[All Fields]) OR "pediatric dentistry"[All Fields]) OR ("dental care for children"[MeSH Terms] OR ("dental"[All Fields] AND "care"[All Fields] AND "children"[All Fields]) OR "dental care for children"[All Fields] OR ("dentistry"[All Fields] AND "children"[All Fields]) OR "dentistry for children"[All Fields]) OR ("pediatric dentistry"[MeSH Terms] OR ("pediatric"[All Fields] AND "dentistry"[All Fields]) OR "pediatric dentistry"[All Fields] OR "pedodontics"[All Fields])) AND ("2007/02/07"[PDat] : "2017/02/03"[PDat] AND "humans"[MeSH Terms] AND ("infant"[MeSH Terms] OR "child"[MeSH Terms] OR "adolescent"[MeSH Terms]))

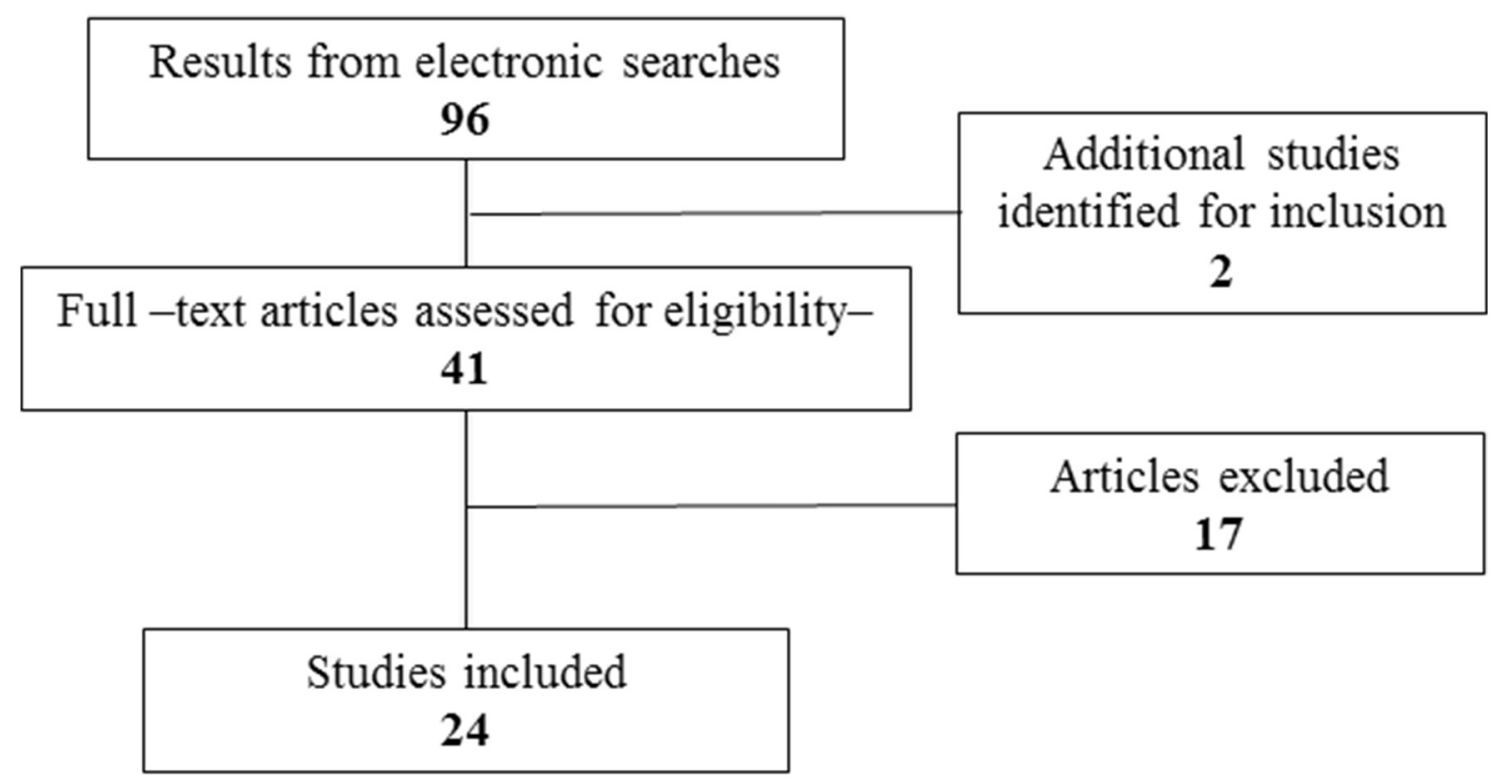

Fig. 1. Flow diagram of eligible studies. 
Table 2. Characteristics and main findings reported from selected studies.

\begin{tabular}{|c|c|c|}
\hline $\begin{array}{l}\text { Authors, year } \\
\text {-country- }\end{array}$ & Design, aims, and methodology & Main clinical findings \\
\hline $\begin{array}{l}\text { Hallet et al. } 1992 \\
\text {-Australia- (3) }\end{array}$ & $\begin{array}{c}\text { Cross-sectional study in which } 39 \text { children with CHD were } \\
\text { compared with } 33 \text { healthy control siblings regarding oral } \\
\text { health status. }\end{array}$ & $\begin{array}{l}\text { Affected children generally suffered from poorer oral } \\
\text { health and should receive vigorous preventive dental } \\
\text { care. This result is likely related with abnormal tooth } \\
\text { formation and with dental neglect. }\end{array}$ \\
\hline $\begin{array}{l}\text { Franco et al. } 1996 \\
\text {-UK- (15) }\end{array}$ & $\begin{array}{l}\text { A comparative cross-sectional study for comparing dental } \\
\text { caries levels, plaque accumulation, gingival inflammation, } \\
\text { oral loading of } S \text {. mutans, Lactobacillus spp., Candida } \\
\text { spp., and salivary IgA levels. } \\
60 \text { matched pairs, aged } 2-16 \text { years. }\end{array}$ & $\begin{array}{c}\text { There were similar levels of caries between affected } \\
\text { and healthy patients. } \\
\text { Proportion of untreated carious lesions was signifi- } \\
\text { cantly higher in the CHD group. } \\
\text { No difference was found regarding oral microbial } \\
\text { loading and salivary IgA amounts }\end{array}$ \\
\hline $\begin{array}{l}\text { Spivack, } 2001 \\
\text {-US- (4) }\end{array}$ & $\begin{array}{l}\text { Overview of Tetralogy of Fallot. } \\
\text { Case report of a 4-year-old boy. }\end{array}$ & $\begin{array}{l}\text { Affected children can be managed safely and effec- } \\
\text { tively. } \\
\text { The oral component is crucial in helping to ensure } \\
\text { long-term success for the pediatric patient. } \\
\text { Good communication and cooperation among the } \\
\text { medical team, the patient, and the family are essential. }\end{array}$ \\
\hline $\begin{array}{l}\text { Balmer \& } \\
\text { Bu'Lock, } 2003 \\
\text {-UK- (11) }\end{array}$ & $\begin{array}{l}\text { A retrospective study. } \\
\text { To examine the degree to which children with CHD had } \\
\text { received professional dental hygiene education. } \\
\text { To evaluate the knowledge of the parents about the relation } \\
\text { of oral health and infective endocarditis. }\end{array}$ & $\begin{array}{l}\text { Despite being received by general dentists, few pa- } \\
\text { tients with CHD received basic education on dental } \\
\text { hygiene/prevention; they were often overlooked. }\end{array}$ \\
\hline $\begin{array}{l}\text { Stecksén-Blicks et } \\
\text { al. } 2004 \text { - } \\
\text { Sweden- (16) }\end{array}$ & $\begin{array}{l}\text { A case-control study for comparing the dental health. } \\
\text { between CHD and gender/age-matched healthy children } \\
43 \text { patients, 3-19 years old. }\end{array}$ & $\begin{array}{l}\text { Children with CHD exhibited poorer dental health } \\
\text { despite intensive oral preventive efforts. } \\
\text { These patients should be referred to the Pediatric } \\
\text { Dentist before they are } 1 \text { year old. }\end{array}$ \\
\hline $\begin{array}{l}\text { Faria-Dutra et al. } \\
2004 \text { - } \\
\text { Brazil- (17) }\end{array}$ & $\begin{array}{c}\text { Observational comparative study to evaluate peripheral } \\
\text { oxygen saturation, heart rate, and blood pressure. } \\
\text { 6-12-year-old patients with cyanotic CHD, undergoing } \\
\text { dental extractions. }\end{array}$ & $\begin{array}{l}\text { There were significant differences between study } \\
\text { groups, but they were considered by the authors to be } \\
\text { "mild and lacking in clinical relevance". }\end{array}$ \\
\hline $\begin{array}{l}\text { Puspa-Pertiwi } \\
\text { et al. } 2007- \\
\text { Indonesia- }(6)\end{array}$ & $\begin{array}{l}\text { Two case reports: a 9-year-old boy and a 4-year-old boy } \\
\text { with Tetralogy of Fallot. } \\
\text { Both patients were administered with Amoxicillin ( } 50 \mathrm{mg} / \\
\text { kg body weight) } 1 \mathrm{~h} \text { before the dental procedures. }\end{array}$ & $\begin{array}{l}\text { Pulse oximetry is recommended to monitor oxygen } \\
\text { saturation and heart pulse, although the child is not } \\
\text { attended under general anesthesia. }\end{array}$ \\
\hline $\begin{array}{l}\text { Tasioula et al. } \\
2008 \text {-UK- (18) }\end{array}$ & $\begin{array}{l}\text { Comparative cross-sectional study. } \\
86 \text { children with CHD and } 60 \text { healthy children, } 2-16 \text { years } \\
\text { of age. } \\
\text { To determine dental caries prevalence and developmental } \\
\text { enamel defects. } \\
\text { To evaluate previous dental treatment. }\end{array}$ & $\begin{array}{c}\text { Children with and without CHD had similar levels of } \\
\text { dental caries. } \\
\text { The care index for primary teeth was higher in pa- } \\
\text { tients with CHD. }\end{array}$ \\
\hline $\begin{array}{l}\text { Babaji, } 2009 \text {-In- } \\
\text { dia- (7) }\end{array}$ & $\begin{array}{c}\text { Case report. } \\
\text { A 4.5-year-old boy with known history of Tetralogy of } \\
\text { Fallot. }\end{array}$ & $\begin{array}{l}\begin{array}{l}\text { Successful dental treatment of children with CHD } \\
\text { depends mainly on in-deep knowledge about the } \\
\text { condition. }\end{array} \\
\text { Anti-anxiety drugs may be necessary to reduce child } \\
\text { stress. } \\
\text { Uncooperative patients can be managed under con- } \\
\text { scious sedation or general anesthesia. } \\
\text { During a hypercyanotic attack, the child should be } \\
\text { placed in the knee-chest position, and receive oxygen } \\
(0.2 \mathrm{mg} / \mathrm{kg} \text { body weight), or be referred to a physician. }\end{array}$ \\
\hline $\begin{array}{l}\text { da Fonseca et al. } \\
2009 \text {-US- (5) }\end{array}$ & $\begin{array}{l}\text { Cross-sectional with standardized questionnaire } \\
\text { To determine the effect of oral health on the quality of life } \\
\text { of young children with CHD. } \\
\text { To examine parental knowledge about the association of } \\
\text { oral health and cardiac disease. }\end{array}$ & $\begin{array}{l}\text { Cardiologists should: (1) Counsel parents to brush the } \\
\text { teeth of their children after the intake of high-sucrose- } \\
\text { content pediatric medications, and (2) Prescribe sugar- } \\
\text { free drugs - pills or tablets-, whenever possible. }\end{array}$ \\
\hline $\begin{array}{l}\text { Rosén et al. } 2010 \\
\text {-Sweden- (19) }\end{array}$ & $\begin{array}{c}\text { A cross-sectional case-control study. } \\
\text { Aim: To compare saliva profiles of children with CHD and } \\
\text { of healthy. } \\
24 \text { age- and gender-matched pairs of children. }\end{array}$ & $\begin{array}{l}\text { Reduced salivary secretion can be a caries risk factor } \\
\text { in medicated children with CHD. }\end{array}$ \\
\hline
\end{tabular}


Table 2 continue. Characteristics and main findings reported from selected studies.

\begin{tabular}{|c|c|c|}
\hline $\begin{array}{l}\text { Suvarna-Reshma } \\
\text { et al. } 2011 \text {-India- } \\
\text { (20) }\end{array}$ & $\begin{array}{c}\text { The oral health of children with CHD, but without dental } \\
\text { caries, was assessed before and following preventive treat- } \\
\text { ment. } \\
76 \text { affected patients and } 30 \text { healthy siblings aged between } \\
5 \text { and } 16 \text { years. } \\
\text { Salivary samples were taken to detect } S \text {. mutans and } S \text {. } \\
\text { mitior. }\end{array}$ & $\begin{array}{c}\text { Poor oral health continued to be prevalent in the ex- } \\
\text { perimental group, indicating a lack of knowledge of } \\
\text { the maintenance of oral hygiene. } \\
\text { Preventive measures decrease the incidence of bac- } \\
\text { teremia, not only during dental procedures, but also } \\
\text { in daily activities such as brushing, eating, and swal- } \\
\text { lowing. }\end{array}$ \\
\hline $\begin{array}{l}\text { Zavala-Cornejo et } \\
\text { al. } 2011 \text {-Colom- } \\
\text { bia- (21) }\end{array}$ & $\begin{array}{l}\text { A narrative review on dental management of children with } \\
\text { Teratology of Fallot. }\end{array}$ & $\begin{array}{l}\text { Authors provide a useful flow-diagram for managing } \\
\text { affected children in the clinical setting. }\end{array}$ \\
\hline $\begin{array}{l}\text { Hedge et al. } 2012 \\
\text {-India- (22) }\end{array}$ & $\begin{array}{l}\text { A comparative cross-sectional study to compare oral hy- } \\
\text { giene status, prevalence and severity of gingivitis, dental } \\
\text { caries, and salivary status. } \\
71 \text { children with CHD vs. } 50 \text { healthy controls aged be- } \\
\text { tween } 6 \text { and } 10 \text { years. } \\
\text { Salivary sialic acid levels were estimated. }\end{array}$ & $\begin{array}{c}\text { Salivary sialic acid levels were higher in children with } \\
\text { CHD with their compromised dental health, compared } \\
\text { with their healthy siblings. } \\
\text { Estimation of sialic acid levels in saliva might predict } \\
\text { chronic inflammatory response in children with poor } \\
\text { oral-health status. }\end{array}$ \\
\hline $\begin{array}{l}\text { Moskovitz et al. } \\
2012 \text {-Israel- (23) }\end{array}$ & $\begin{array}{l}\text { Case report of a brain abscess in a child with cyanotic } \\
\text { CHD due to an infected primary molar. } \\
\text { S. intermedius is found in root canals of primary with } \\
\text { apical periodontitis; it was isolated from the cerebrospinal } \\
\text { fluid. }\end{array}$ & $\begin{array}{l}\text { CHD is a risk factor for the development of brain } \\
\text { abscesses of odontogenic origin. } \\
\text { It is important for Pediatric Cardiologists to refer } \\
\text { their patients with CHD as early as possible for dental } \\
\text { checkups. }\end{array}$ \\
\hline $\begin{array}{l}\text { Cavalcanti-Pi- } \\
\text { mentel et al. } 2013 \\
\text {-Brazil- (24) }\end{array}$ & $\begin{array}{l}\text { A cross-sectional study for analyzing the oral epidemio- } \\
\text { logical profile and caries experience. } \\
144 \text { children with CHD aged between } 3 \text { and } 5 \text { years. }\end{array}$ & $\begin{array}{l}\text { Young children with CHD had poor oral health and } \\
\text { high levels of caries experience. } \\
\text { Risk factors detected: Cyanosis, negative behavior, } \\
\text { daily use of medicine, one-parent family, and educa- } \\
\text { tional level. }\end{array}$ \\
\hline $\begin{array}{l}\text { Nosrati et al. } 2013 \\
\text {-US- (12) }\end{array}$ & $\begin{array}{l}\text { To evaluate the gingival status of children with CHD. } \\
7-13 \text { years of age. } \\
25 \text { children with CHD vs. } 25 \text { healthy age- and gender- } \\
\text { matched children. }\end{array}$ & $\begin{array}{c}\text { Patients with CHD exhibited higher prevalence of } \\
\text { periodontal disease (gingivitis, plaque, calculus, and } \\
\text { recession). }\end{array}$ \\
\hline $\begin{array}{l}\text { Dunlop et al. } 2013 \\
\text {-US- (25) }\end{array}$ & $\begin{array}{l}\text { To identify treatment options recommended by AAPD } \\
\text { members, concerning pulp treatments in primary teeth of } \\
\text { children with CHD. }\end{array}$ & $\begin{array}{l}\text { Presence of CHD affects treatment decisions in cases of } \\
\text { irreversible pulpitis and symptomatic apical periodonti- } \\
\text { tis, but not in teeth with reversible pulp inflammation. }\end{array}$ \\
\hline $\begin{array}{l}\text { Cantekin et al. } \\
2013 \text {-Turkey- (26) }\end{array}$ & $\begin{array}{l}\text { A case-control study. } \\
\text { To compare caries experience and oral hygiene. } \\
\text { To quantify the persistence of a delay in the dental age of } \\
\text { children with CHD. } \\
268 \text { age-matched children and adolescents (3-16 years of age). }\end{array}$ & $\begin{array}{l}\text { Authors found significantly higher rates in Decayed } \\
\text { Missing Filled (DMF) indices. } \\
\text { Dental ages of children with CHD were significantly lower. } \\
\text { These findings might explain the negative impacts on } \\
\text { dental development in patients with CHD. }\end{array}$ \\
\hline $\begin{array}{l}\text { Hasan \& Chan, } \\
2014 \text {-Malaysia- } \\
(27)\end{array}$ & $\begin{array}{l}\text { Three case reports on management of children with cya- } \\
\text { notic CHD for dental extractions under general anesthesia. } \\
\text { A Dexmedetomidine (a sedative drug)-Ketamine combina- } \\
\text { tion and oxygen supplementation were employed. }\end{array}$ & $\begin{array}{l}\text { The pharmacological combination may be clinically } \\
\text { safe and effective for children with cyanotic CHD. }\end{array}$ \\
\hline $\begin{array}{l}\text { Ajami et al. } 2015 \\
\text {-Iran- (28) }\end{array}$ & $\begin{array}{l}\text { A cross-sectional study, with the aim of evaluating the rate } \\
\text { of oral S. mutans in saliva and the caries rate in children } \\
\text { with congenital or acquired heart disease. } \\
66 \text { affected patients vs. } 50 \text { healthy controls. } \\
\text { Patients with acquired disease took Penicillin as prophy- } \\
\text { laxis monthly. }\end{array}$ & $\begin{array}{c}\text { Children with CHD showed significantly higher } S \text {. } \\
\text { mutans rates than children with acquired heart disease } \\
\text { and healthy controls. } \\
\text { Authors recommend that antibiotic prophylaxis be } \\
\text { also used in children with CHD with high risk of } \\
\text { caries, especially during the early stage of the first } \\
\text { permanent molar eruption. }\end{array}$ \\
\hline $\begin{array}{l}\text { Cantekin et al. } \\
2015 \text {-Turkey- (29) }\end{array}$ & $\begin{array}{l}\text { A comparative study to determine developmental enamel } \\
\text { defects and dental treatment conditions. } \\
72 \text { diseased vs. } 56 \text { healthy children aged 3-14 years. }\end{array}$ & $\begin{array}{c}\text { No significant difference in both outcome variables. } \\
\text { However, patients with CHD exhibited a lower oral- } \\
\text { care rate, with more extracted primary teeth and } \\
\text { delayed dental treatment. }\end{array}$ \\
\hline $\begin{array}{l}\text { Ayala \& Aguayo, } \\
2016 \text {-Mexico- (8) }\end{array}$ & $\begin{array}{l}\text { Case report of a 4-year-old boy with Tetralogy of Fallot } \\
\text { and epilepsy. } \\
\text { Severe early-childhood caries. } \\
\text { Antibiotic prophylaxis consisted of Clindamycin ( } 20 \mathrm{mg} / \\
\text { kg body weight) intravenously, } 30 \text { min before the proce- } \\
\text { dures. }\end{array}$ & $\begin{array}{l}\text { Dental management of CHD is based on a detailed } \\
\text { medical and dental history to achieve a proper diagno- } \\
\text { sis and treatment plan. } \\
\text { Close interconsultation of the Pediatric Cardiologist is } \\
\text { strongly suggested to decrease the risk of developing } \\
\text { additional systemic complications. }\end{array}$ \\
\hline $\begin{array}{l}\text { Sivertsen et al. } \\
2016 \text {-Norway- (10) }\end{array}$ & $\begin{array}{l}\text { A cross-sectional study; } 3 \text { years in duration. } \\
\text { Aim: To compare dentine caries prevalence between } \\
\text { 5-year-old children with CHD and general population. }\end{array}$ & $\begin{array}{l}\text { Caries prevalence at dentine level was significantly higher. } \\
\text { More than one third of children with CHD exhibited an } \\
\text { oral health status implying risk for systemic hazardous } \\
\text { effects. }\end{array}$ \\
\hline
\end{tabular}


Table 3. Incidence of bacteremia following diverse dental procedures on primary teeth $(35,37)$.

\begin{tabular}{|l|c|}
\hline \multicolumn{1}{|c|}{ Oral procedure } & \% \\
\hline & \\
Baseline rate & 9 \\
Intraligamentary injection & 96.6 \\
Multiple extractions (e.g. 4) & 51 \\
Single extraction & 39 \\
Mucoperiosteal flap & 39 \\
Tooth brushing & 38.5 \\
Matrix band placement with wedge & 32 \\
Rubber-dam placement & 29.4 \\
Ultrasonic scaling of teeth & 25 \\
Polishing teeth & 24.5 \\
Slow-speed drill & 13 \\
High-speed drill & 4 \\
\hline
\end{tabular}

(i) Prevalence of dental caries. Studies on dental caries prevalence in children with PA/VSD have shown variable results (11). Hallet et al. (3) reported increased higher levels of caries in affected children when compared with healthy siblings. Similar results were reported in two studies performed with pre-school participants in Sweden (16) and Brazil (24). Also, significantly higher levels of salivary Streptococcus mutans levels and caries rates were detected in Iranian affected patients (28). However, Franco et al. (15) found no differences in decayed/missing/filled teeth (dmft) or Decayed/Missing/ Filled Teeth (DMFT) between cardiac and control children aged 2-16 years. Ayala \& Aguayo (8) mention that among patients with PA/VSD, those treated with Digoxin demonstrate a greater number of carious lesions. On the other hand, a consistent outcome found in the present scoping review was the higher degree of untreated caries, delayed treatment, and decreased level of dental care in patients with PA/VSD $(1,11,15,26,29)$. These conditions may lead to multiple extractions of primary teeth, possibly requiring general anesthesia $(24,26)$.

(ii) Prevention of dental disease (oral hygiene and diet). Maintaining oral health in children with PA/VSD is ex- tremely important because the oral cavity is the chief entrance via for bacteria that may cause infective endocarditis, which increases the risk of additional damage to the heart condition (1). Chronic administration of liquid sucrose-sweetened oral drugs increases the incidence of dental caries and gingivitis, particularly in young children and in cases of developmental enamel defects $(8,20)$. Additionally, administered diuretics may lead to impaired salivary secretion or xerostomia $(16,19)$. Further, many children with PA/VSD have difficulties with feeding and nutrition, particularly during their first year of life, mainly vomiting during breastfeeding, reduced appetite, and low weight gain due to increased energy consumption (10). In order to compensate for these deficiencies, parents usually pamper their children with frequent meals based on glucose/fat foods or drinks; night meals are often necessary to maintain an acceptable level of energy intake $(10,16,22)$.

Thus, an aggressive preventive/restorative program must be implemented in these patients as early as possible, focused primarily on exhaustive oral hygiene, fluoride varnish applications, dietary counseling, pit and fissure sealants, maintenance of good gingival/periodontal health, and the eradication of carious lesions and local infection processes $(6,11-13,16)$.

(iii) Bacteremia and infective endocarditis risk. Approximately one-eighth of children with CHD may develop infective endocarditis if exposed to oral bacteremia after a dental procedure $(1,6,11)$. The most common bacteria, associated in $>60 \%$ of patients with endocarditis and found in the oral cavity and pulp canals of infected primary teeth, are Staphylococcus aureus, group B (Viridans) streptococci (e.g., Streptococcus mutans, Streptococcus sanguis, and Streptococcus mitis), and enterococci $(20,23,34)$. These bacteria may reach the bloodstream through the dental pulp and periodontal pockets (10). Patients with a history of repaired or unrepaired CHD, rheumatic heart fever, transplants, or presence of artificial heart valves, implants, shunts, conduits, or catheters may require antibiotic prophylaxis prior to any invasive dental treatment (e.g., deep scaling, extractions, pulpotomy/pulpectomy, clamping

Table 4. Antibiotic prophylaxis regimens for dental procedures in children -adapted from AAPD (13) and Zavala-Cornejo et al. (21).

\begin{tabular}{|l|l|c|}
\hline \multirow{2}{*}{ Clinical situation } & \multicolumn{2}{c|}{ Single dose regimen (30-60 min before procedures) } \\
\cline { 2 - 3 } & \multicolumn{1}{|c|}{ Antimicrobial agent } & Doses (mg/kg body wt) \\
\hline Via oral & Amoxicillin & 50 \\
\hline Unable to take oral drugs & $\begin{array}{l}\text { Ampicillin or Cefazolin or Ceftriaxone } \\
\text { (IM or IV) }\end{array}$ & 50 \\
\hline $\begin{array}{l}\text { Allergic to Penicillin or Ampicillin } \\
\text { (via oral) }\end{array}$ & $\begin{array}{l}\text { Cephalexin } \\
\text { or Clindamicyn } \\
\text { or Azithromicyn or Clarithromicyn }\end{array}$ & 50 \\
\hline $\begin{array}{l}\text { Allergic to Penicillin or Ampicillin } \\
\text { (unable to take oral drugs) }\end{array}$ & $\begin{array}{l}\text { Cefazoline or Ceftriaxone (IM or IV) } \\
\text { or Clindamicyn (IM or IV) }\end{array}$ & 20 \\
\hline
\end{tabular}


and banding, or any procedure involving manipulation of gingival or periapical tissues or perforation of oral mucosa) (Table 3) $(6,13,18,34,35-37)$.

According to Hallet et al. (3), there is an increased risk of endocarditis from residual infection in primary tooth canals, which are difficult to debride thoroughly. That is the reason that several authors suggest the extraction/ space maintainer vs. a pulpectomy procedure in primary teeth; they recommend endodontic procedures only in permanent teeth with straight canals and closed apex (7). According to Jain et al. (36), incidence and magnitude due to canal instrumentation not extending to the periapical tissue are very low, and nearly all bacteria are eliminated from the blood within $10 \mathrm{~min}$. Poor oral hygiene affects the frequency of oral bacteremia following daily practices such as chewing, flossing, and brushing. Different antibiotic prophylaxis regimens for dental procedures in children are depicted in Table $4(13,21)$.

(iv) Child behavior control and treatment under general anesthesia. Severely affected children may have reduced tolerance to the stress or anxiety when dental treatment is provided. Thus, dental treatment should be administered under stress-free conditions, thereby preventing cyanotic events $(4,8)$. Very poorly cooperative patients may be managed with either conscious sedation or under general anesthesia (7). This latter procedure poses many challenges to Anesthesiologists because of the diverse problems associated with CHD (e.g., chronic hypoxemia, risk of brain abscess, pulmonary hypertension, and bacterial endocarditis), mainly due to the anesthetic technique and to perioperative drugs, which can affect the patient's physiologic status during surgery (27). Also, general anesthesia may require additional financial resources (e.g., especial care and hospitalization), together with psychological and physical burdens for the child and her/his family (11).

Strengths and weaknesses. The current scoping review carefully followed the recommendations stated by Arksey and O'Malley (14) for screening papers and extracting relevant data from them. However, as in any scoping review, a significant weakness was that a critical methodological quality and the risk of bias of each article could not be assessed. Additionally, only English and Spanish language articles were reviewed; despite the latter limitation and the small number of published articles regarding pulmonary atresia with ventricular septal defect in the pediatric dentistry field, we are confident that sufficient reliable and useful information could be collected and synthesized, with the purpose of aiding clinicians to better understand this pathological condition.

- Additional clinical recommendations (1,3,4,7,20,21):

- A thorough review is essential of the child's history, symptoms, and current medical status.

- Children should be instructed to avoid vigorous brushing.
- Ideally, dental treatments should be provided during the morning, during short appointments, with 2-4 week intervals between these.

- Before cardiac surgery, the child is dentally treated to eliminate potential or active oral infective sites.

- Patient's oral cavity should be rinsed with 0.2 chlorhexidine gluconate before any dental procedure.

- If a hypercyanotic attack occurs, the child should be placed in a knee-chest position, administer oxygen ( 0.2 $\mathrm{mg} / \mathrm{kg}$ body weight), and refer to the Pediatrician.

- Practitioners must take in account potential drug interactions with chronic medications administered to affected patients, particularly in those with severe hematological (coagulation), respiratory, and immunological problems.

\section{Conclusions}

The relationship between oral and systemic health should be consistently reinforced, especially to parents of children with cardiac diseases. Thus, Pediatric Dentists, Cardiologists, and other associated health practitioners should work together in order to educate children affected with PA/VSD and their parents and also to enhance oral health-related quality of life in this vulnerable population.

\section{References}

1. FitzGerald K, Fleming P, Franklin O. Dental health and management for children with congenital heart disease. Prim Dent Care. 2010;17:21-5.

2. Barron DJ. Tetralogy of Fallot: Controversies in early management. World J Pediatr Congenit Heart Surg. 2013;4:186-91.

3. Hallet KB, Radford DJ, Seow WK. Oral health of children with congenital cardiac diseases: A controlled study. Pediatr Dent. 1992;14:224-30.

4. Spivack E. Tetralogy of Fallot: An overview, case report, and discussion of dental implications. Spec Care Dentist. 2001;21:172-5.

5. da Fonseca MA, Evans M, Teske D, Thikkurissy S, Amini H. The impact of oral health on the quality of life of young patients with congenital cardiac disease. Cardiol Young. 2009;19:252-6.

6. Puspa-Pertiwi AS, Sutherna-Sasmita I, Herdiati-Nonong Y. Oral and dental management in children with tetralogy of Fallot. Dent J. 2007;40:42-5.

7. Babaji P. Tetralogy of Fallot: A case report and dental considerations. Rev Clin Pesq Odontol. 2009;5:289-92.

8. Ayala C, Aguayo L. Oral and systemic manifestations, and dental management of a pediatric patient with Tetralogy of Fallot. A case report. J Oral Res. 2016;5:87-91.

9. Montero JV, Nieto EM, Vallejo JR, Montero SV. Intranasal midazolam for the emergency management of hypercyanotic spells in tetralogy of Fallot. Pediatr Emerg Care. 2015;31:269-71.

10. Sivertsen TB, Abmus J, Greve G, Astrom AN, Skeie MS. Oral health among children with congenital heart defects in Western Norway. Eur Arch Paediatr Dent. 2016;17:397-406.

11. Balmer R, Bu'Lock FA. The experiences with oral health and dental prevention of children with congenital heart disease. Cardiol Young. 2003;13:439-43.

12. Nosrati E, Eckert GJ, Kowolik MJ, Ho JG, Schamberger MS, Kowolik JE. Gingival evaluation of the pediatric cardiac patient. Pediatr Dent. 2013;35:456-62.

13. American Academy of Pediatric Dentistry (AAPD). Reference 
Manual. Guideline on antibiotic prophylaxis for dental patients at risk for infection Pediatr Dent. 2015;37:292-7.

14. Arksey H, O'Malley L. Scoping studies: Towards a methodological framework. Int J Soc Res Methodol. 2005;8:19-32.

15. Franco E, Saunders CP, Roberts GJ, Suwanprasit A. Dental disease, caries related microflora and salivary IgA of children with severe congenital cardiac disease: An epidemiological and oral microbial survey. Pediatr Dent. 1996;18:228-35.

16. Stecksén-Blicks C, Rydberg A, Nyman L, Asplund S, Svanberg C. Dental caries experience in children with congenital heart disease. Int J Paediatr Dent. 2004;14:94-100.

17. Faria-Dutra RM, Itagiba-Neves IL, Simoes-Neves R, Atik E. Peripheral oxygen saturation, heart rate, and blood presure during dental treatment of children with cyanotic congenital heart disease. Clinics (Sao Paulo). 2014;69:314-8.

18. Tasiuola V, Balmer R, Parsons J. Dental health and treatment in a group of children with congenital heart disease. Pediatr Dent. 2007;30:323-8.

19. Rosén L, Rydberg A, Sjöström I, Stecksén-Blicks C. Saliva profiles in children using heart failure medication: A pilot study. Eur Arch Paeditr Dent. 2010;11:187-91.

20. Suvarna-Reshma M, Rai K, Hedge-Amitha M. Oral health of children with congenital heart disease following preventive treatment. J Clin Pediatr Dent. 2011;36:93-8.

21. Zavala-Cornejo KV, Vinitzky-Brener IV, Ramírez-Bouchan D. Manejo estomatológico del paciente pediátrico con cardiopatía congénita. Revisión de la literatura. Univ Odontol. 2011;30:57-66.

22. Hedge AM, Rai K, Sushma KS, Shetty S. Salivary sialic acid levels and dental health in children with congenital heart disease. J Clin Peditar Dent. 2012;36:293-6.

23. Moskovitz M, Birenboim R, Katz-Sagi H, Perles Z, Averbuch D. A brain abscess of probable odontogenic origin in a child with cyanotic heart disease. Pediatr Dent. 2012;34:403-6.

24. Cavalcanti-Pimentel EL, Pereira-Azevedo VM, Lima-Castro RA, Carvalho-Reis L, De Lorenzo A. Caries experience in young children with congenital heart disease in a developing country. Braz Oral Res. 2013;27:103-8.

25. Dunlop RM, Sanders BL, Jones JE, Walker LA, Caldwell RL. Pulp therapy in pediatric patients with congenital heart diseases: Survey of American Academy of Pediatric Dentistry members. Pediatr Dent. 2013;80:139-44.

26. Cantekin K, Cantekin I, Torun Y. Comprehensive dental evaluation of children with congenital or aquired heart disease. Cardiol Young. 2013;23:705-10.

27. Hasan MS, Chan L. Dexmedetomidine and ketamine sedation for dental extraction in children with cyanotic heart disease. J Oral Maxillofac Surg. 2014;72:1920.e1-1920.e4.

28. Ajami B, Abolfathi G, Mahmoudi E, Mohammadzadeh Z. Evaluation of salivary Streptococcus mutans and dental caries in children with heart diseases. J Dent Res Dent Clin Dent Prospects. 2015;9:105-8.

29. Cantekin K, Gumus H, Torun YA, Sahin H. The evaluation of developmental enamel defects and dental treatment conditions in a group of Turkish children with congenital heart disease. Cardiol Young. 2015;25:312-6.

30. Colquhoun H, Levac D, O'Brien KK, Straus S, Tricco AC, Perrier L, et al. Scoping reviews: Time for clarity in definition, methods, and reporting. J Clin Epidemiol. 2014;67:1291-4.

31. Fleming PS, Koletsi D, O'Brien K, Tsichlaki A, Pandis N. Are dental researchers asking patient-important questions? A scoping review. J Dent. 2016;49:9-13.

32. Levac D, Colquhoun H, O'Brien KK. Scoping studies: Advancing the methodology. Implement Sci. 2010;5:69-77.

33. Davis K, Drey N, Gould D. What are scoping studies? A review of the nursing literature. Int J Nurs Stud. 2009;46:1386-400.

34. Allen U. Infective endocarditis: Updated guidelines. Pediatr Child Health. 2010;15:205-8.
35. Roberts GJ, Holzel HS, Sury MRJ, Simmons NA, Gardner P, Longhurst P. Dental bacteremia in children. Pediatr Cardiol. 1997;18:24-7.

36. Jain A, Samant PS, Kumar N, Sinha S, Verma K. Endodontic considerations in a medically compromised patient: An overview. Asian J Oral Health Allied Sci. 2013;3:66-73.

37. Brincat M, Savarrio L, Saunders W. Endodontics and infective endocarditis - is antimicrobial chemoprophylaxis required? Int Endod J. 2006;39:671-82.

\section{Conflicts of interest}

The authors declare that they have no conflicts of interest. 